\title{
THE IMPACT OF THE AACSB ACCREDITATION ON ENROLLMENT GROWTH AT HBCU (HISTORICALLY BLACK COLLEGES AND UNIVERSITIES) BUSINESS SCHOOLS
}

\author{
DOI: 10.17261/Pressacademia.2018.832 \\ RJBM- V.5-ISS.2-2018(5)-p.130-141
}

Legima E. Doh', Damian R. Prince², Michael P. McLain ${ }^{3}$, Sid Howard Credle ${ }^{4}$

${ }^{1}$ Hampton University, School of Business, Virginia, USA.

legima.doh@my.hamptonu.edu, ORCID: 0000-0003-3412-1022

${ }^{2}$ New Jersey City University, School of Business, New Jersey, USA.

dprince@njcu.edu ,ORCID: 0000-0003-2497-5905

${ }_{3}^{3}$ Hampton University, School of Business, Virginia, USA.

mcklaipm@gmail.com, ORCID: 0000-0002-8697-3377

${ }^{4}$ Hampton University, School of Business, Virginia, USA.

sid.credle@my.hamptonu.edu, ORCID: 0000-0002-6445-4680

\section{To cite this document}

Doh, L., Prince, D., McLain, M., Credle S.H., (2018). The impact of the AACSB accreditation on enrollment growth at HBCU (historically Black Colleges and Universities) business schools. Research Journal of Business and Management (RJBM), V.5(2), p.130-141.

Permanent link to this document: http://doi.org/10.17261/Pressacademia.2018.832

Copyright: Published by PressAcademia and limited licenced re-use rights only.

\begin{abstract}
Purpose- Most research on the benefits of the AACSB accreditation has been focused on financially well-off and research-based institutions. Consequently, there is limited literature on the AACSB accreditation with regard to HBCUs. Over the years, general decline in Business School enrollment, and the heavy reliance of HBCUs on tuition revenue have made enrollment an increasingly important determinant of their survival. In this article, we investigate whether the AACSB accreditation yields greater enrollment growth at HBCU Business Schools and explore alternative business school accreditations.

Methodology- This study is based on quantitative methods wherein we collected data from secondary sources and used statistical models to test our hypotheses.

Findings- Our results show that the AACSB accreditation does not lead to greater enrollment growth at HBCU Business Schools.

Conclusion- We suggest that HBCUs should not base their decision to pursue the AACSB accreditation on the expectation of greater enrollment growth, but on other factors; and should consider the ACBSP and IACBE as viable options.
\end{abstract}

Keywords: Historically Black College or University (HBCU), business schools, accreditation, business school accreditation, enrollment JEL Codes: M1,M2, 12

Historically Black College or University (HBCU)- The Higher Education Act of 1965, as amended, defines an HBCU as: “...any historically
black college or university that was established prior to 1964, whose principal mission was, and is, the education of black Americans, and
that is accredited by a nationally recognized accrediting agency or association determined by the Secretary [of Education] to be a reliable
authority as to the quality of training offered or is, according to such an agency or association, making reasonable progress toward
accreditation" (White House Inititaive on Historically Black Colleges and Universities, 2018).
Business School- An "educational institution that specializes in the teaching of material relevant to business and or business service, [it can
also be known as either a school of management or a school of business administration]" (Business School, 2018).
Accreditation- A voluntary evaluation process by which an academic institution or program holds itself out for review by an external
organization and is measured against a set of predetermined standards (Sciglimpaglia, et al., 2006).
Business School Accreditation- A specialized accreditation that is awarded to business schools (Sciglimpaglia, et al., 2006).
Enrollment- The number of individuals (students) registered in a course(s) at any given time of an academic year.

\section{INTRODUCTION}

Accreditation of colleges and universities in the United States (U.S.) determines if an institution meets or exceeds minimum standards of quality (Importance of Accreditation, 2018). Therefore, accreditation is important because it helps students determine acceptable institutions for enrollment. There are two kinds of academic accreditation: institutional (regional) and specialty (program) (Importance of Accreditation). Institutional accreditation is for monitoring the educational quality of an entire college or university, while specialty accreditation is for specific fields of study such as business, medicine, 
nursing or architecture, and is meant to ensure that graduates of the specific fields of study meet professional standards (Guttenplan, 2011).

Since the U.S. government does not regulate accreditation, it appoints other bodies to perform the task (Understanding Accreditation, 2018). The U.S. Secretary of Education recognizes agencies that are considered to be reliable authorities on accreditation and lists these agencies on its website (Understanding Accreditation). Making sure the agency your school is accredited by is on this list is the easiest way to ensure that the accreditation is legitimate.

The most widely recognized institutional/regional accrediting agencies for colleges and universities in the U.S. are: Northwest Commission on Colleges and Universities (NWCCU), Western Association of Schools and Colleges (WASC), New England Association of Schools and Colleges (NEASC), Middle States Commission on Higher Education (MSCHE), Southern Association of Colleges and Schools (SACS) and North Central Association (NCA) (Understanding Accreditation, 2018). The Council for Higher Education Accreditation (CHEA), which is the international authority on post-secondary accreditation maintains a list of agencies it deems reputable on its website (CHEA and USDE-Recognized Accrediting Organizations, 2018). There are three accreditation agencies to consider when looking for business programs in the United States. These include the Association to Advance Collegiate Schools of Business (AACSB), the Accreditation Council for Business Schools and Programs (ACBSP) and the International Assembly for Collegiate Business Education (IACBE). Of these three accreditations, the AACSB is the oldest and is considered the most prestigious accreditor of business education (Guttenplan, 2011).

In choosing to dedicate considerable resources to the pursuit of the AACSB accreditation, school administrators may act with incomplete knowledge of how accreditation impacts various dimensions of a business program, particularly in regard to input costs (Hedrick D, W., Henson, S. E., \& Krieg, J. M., 2010). As a result of their very difficult financial situations, HBCUs have to make well-informed decisions with regard to financial commitments in order to sustain their institutions (Gasman, 2009). Choosing whether or not to pursue the AACSB accreditation must therefore be thoroughly considered due to the huge financial commitment involved.

This study is our attempt to investigate whether or not investing in the AACSB accreditation leads to greater gains in enrollment growth at HBCU Business Schools. To proceed with the study, we provide a literature review on the accreditation process with regard to HBCUs, the financial situation of HBCUs and justification for choosing enrollment as the test metric. Subsequently, we provide information about the data used in the study, define and test our hypotheses, analyze the results of the test, discuss the findings thereof, and make recommendations and suggestions for future studies.

\section{LITERATURE REVIEW}

Since black colleges and universities in the U.S. are found almost exclusively in the south and in border states, most HBCUs are beholden to the Southern Association of Colleges and Schools (SACS) for official endorsement (see Table 1). SACS has been the most active of the regional accrediting associations in its public sanctioning of institutions (Credle et. al, 2010). It has been criticized for its disproportionate attention to HBCUs (Credle). According to faculty members Saran Donahoo and Wynetta Lee, between 1996 and 2005, 25 percent of SACS's sanctions pertained to black colleges, while these institutions made up only 13 percent of the SACS institutional membership (Credle). In addition, since 1989, nearly half of the twenty institutions that lost their accreditation from SACS were historically black (Credle). Most reprimands and revocations of accreditation are due to financial deficits; however, faculty quality (degrees), campus infrastructure, student enrollment, library holdings, etc., play a role in the certification process.

Institutional accreditation has been tied to federal financial aid since the passage in 1952 of the Readjustment Assistance Act. Unaccredited institutions are not eligible to be awarded federal and state student aid, including veterans' benefits, loans and grants. Since unaccredited private black colleges cannot be members of the United Negro College Fund, these institutions lose access to this additional source of funding, which may be needed to sustain their operating budgets. According to Fast facts - Historically Black Colleges and Universities (2018), of the 102 HBCUs, 51 are public institutions and 51 are private institutions. Therefore, if sanctioned by the SACS, half of HBCUs as a result of being private risk losing access to this source of funding.

The AACSB, ACBSP and IACBE fall outside the federal requirement because specialty accreditations are optional for business schools and do not affect their eligibility for federal aid. Business schools can choose among the three, "but most of them seek AACSB approval as a badge of quality" (Terhune, 2011, p. 1).

There are two main reasons for the precarious financial situation of HBCUs. First, these institutions serve a student population that is disproportionately low-income (Gasman, 2009). Reflecting the institutions' commitment to educating low-income students, HBCU tuition rates tend to be 50 percent lower than those of their historically white counterparts (Gasman). Lower tuition rates equals fewer operating dollars, which means less flexibility during tough times. The second reason is that HBCUs have smaller endowments than other institutions and rely more heavily on tuition revenue (Gasman). Of the nation's 102 HBCUs, only three-Howard University, Spelman College, and Hampton University-have endowments 
in the top three hundred of all U.S. institutions of higher education. Smaller endowments mean fewer dollars available for operating costs and institutional financial aid.

Due to the proliferation of business schools (traditional and on-line) in the U.S., as well as an increase in competition from additional colleges and universities, corporations and on-line universities that offer similar programs of study and degrees, many business schools are facing a decline in student enrollment. According to Kelsey (2017) applications to full-time MBA programs in the U.S. fell a third straight year, the latest signal that business schools are struggling to entice young professionals out of a strengthening job market. As a result, student recruitment has become more important to many schools, and accreditation is a key element in attracting students (Kemelgor, Johnson and Srinivasan, 2000). In October 2011, in order to bring the PLUS credit standards in line with those of banks, the U.S. Department of Education tightened the credit history standards for PLUS loans. In the first full school year that the new standards were in place (2012/13), the total dollar amount of federal loans approved for parents fell 11 percent (Anderson, 2013). Enrollment at HBCUs declined the year after credit standards were tightened (2012/13), and the decrease was larger than at other institutions, corresponding to the larger decline in PLUS loan recipients at HBCUs (Johnson, Bruch \& Gill, 2015). Whittenburg, Toole, Sciglimplagia, and Medlin (2004) have discussed the process of accreditation, with associated costs and benefits. In that study, they defined five general constructs. The constructs are: (1) cost of accreditation, (2) internal process, (3) benchmarking, (4) attracting students and (5) obtaining organizational support.

Regional accredition is required, before a business program can seek and secure specialty accreditation. As stated before, the majority of HBCUs are beholden to SACS for institutional accreditation. Enrollment is one of the accreditation requirements of the SACS. In the same light, it is one of the key operationl performance indicators identified by the ACBSP, one of the three specialty accreditation agenices. In comparison to their white counterparts, HBCUs have lower tuition rates and smaller endowments, but rely more heavily on tuition revenue. Due to this heavy reliance on tuition revenue over time, enrollment has become a key determinant of survival of HBCUs. Investigating whether investing in the AACSB accreditation leads to greater enrollment growth would provide information that HBCUs can use to make informed judgments about their choice of business school/program accreditation.

\subsection{The Association to Advance Collegiate Schools of Business (AACSB)}

Founded in 1916, AACSB provides quality assurance, business education intelligence, and professional development services to over 1,500-member organizations and more than 800 accredited business schools worldwide (AACSB Accreditation Standards, 2018). The association is the oldest and most prestigious accreditor of business education (Guttenplan, 2011). According to information gathered from the AACSB website, the mission of the AACSB International is to foster engagement, accelerate innovation, and amplify impact in business education. It provides internationally recognized, specialized accreditation for business and accounting programs at the bachelor's, master's and doctoral level. Its core values are: quality, inclusion and diversity, global mindset, ethics, social responsibility and community. An applicant for accreditation must be able to show that it has the structure and capacity to deliver and sustain high-quality management education and intellectual contributions. Unless it can do so transparently, it is not prepared to be evaluated against the 15 AACSB accreditation eligibility standards. Among its many standards is faculty advancement, which is based on the attainment of research grants and research publication (i.e. publish or peril). Of significant importance to HBCUs is Standard 3: Financial Strategies and Allocation of Resources - the school has financial strategies to provide resources appropriate to and sufficient for achieving its mission and action items.

Since its establishment, AACSB has worked to advance diversity and inclusion issues within the organization, its member schools, and the global business community through initiatives such as: the PhD Project, the Women Administrators in Management Education affinity group, the PhD Pipeline program and, most recently, with its Visioning Initiative, which challenges global business schools to examine their relationship to society, the business community, and the higher education sector (AACSB, 2018). According to Financial Times (2016), 96\% of the chief executives of fortune 500 companies attended an AACSB-accredited business school. 90\% of the Economist's top 1002016 MBA programs were housed in business schools that achieved AACSB accreditation. Four out of five alumni from AACSB-accredited schools felt that their graduate management education contributed to improvements in their competitiveness, pro-activeness, innovativeness and creativity (GMAC, 2015). Yet, some schools decide not to be accredited by AACSB, mostly due to the low flexibility of the accreditation standards, the high cost to obtain and maintain the accreditation and a lack of pressure from stakeholders (Sciglimpaglia et al., 2006).

AACSB standards are mostly based on research excellence, but also on high quality faculty, classroom and curricula excellence and continuous program improvement (Roller, Andrews and Bovee, 2003). The AACSB accreditation process is, by far, the most studied as it promotes excellence and continuous program improvement (Henninger, 2000). Research on the AACSB accreditation has primarily been focused on research-based institutions and predominantly large public universities. Consequently, there is a dearth of literature about it in relation to HBCUs. 
The cost of AACSB accreditation includes an initial business/accounting accreditation visit application fee of $\$ 14,000$, deferral visit fee of $\$ 5,000$, and an annual accreditation fee of $\$ 5,400$ which increases to $\$ 8,700$ for schools that hold both business and accounting accreditations (AACSB, 2018).

\subsection{The Accreditation Council for Business Schools and Programs (ACBSP)}

Based on information reported on its website, the ACBSP was founded on April 28, 1988. It accredits quality business programs at the associate, baccalaureate, master's and doctoral degree levels across the globe at more than 1,000 institutions. There are currently 2,983 ACBSP accredited business programs worldwide. ACBSP understands the importance placed on outcomes assessment from external stakeholders, which is why student learning outcomes assessment is a threshold standard for ACBSP accreditation. Examples of outcomes assessment in connection to student learning are; key operational performance indicators (enrollment, graduation rate and retention rate), stakeholder satisfaction (student satisfaction and alumni satisfaction), and faculty focus (professional development, scholarly activity, and faculty qualification). The ACBSP is recognized as a leader in the area of assessing student-learning outcomes. It's accreditation process follows the Baldrige model and focuses on recognizing teaching excellence, determining student learning outcomes, and continuous improvement.

The accreditation process is outlined on the ACBSP websites as follows: the first step is to join as an ACBSP member, the next step is to complete and submit the candidacy form, along with the candidacy fees (ACBSP Accreditation, 2018). A preliminary questionnaire also needs to be submitted (ACBSP Accreditation). A mentor then provides a gap analysis and authorization to proceed to the full self-study (ACBSP Accreditation). Once the self-study is completed and submitted, dates are determined for a site-visit of the institution. Depending on when the site-visit is conducted, decisions are announced either in April or November. For an institution to be accredited, it must meet the overall requirements of the six ACBSP standards.

The ACBSP Board of Directors authorized a change in the membership dues structure for 2017 (Rafol, 2017). Annual membership dues for the 2017-18 was increased to $\$ 2,000$ for member-only institutions (Rafol). Membership dues for ACBSP accredited institutions and those in candidacy were increased from $\$ 2,150$ to $\$ 2,600$ for the main campus and $\$ 1,000$ for additional campuses (Rafol). Despite the increase, ACBSP accreditation is still the least expensive among the 3business school/program accreditations available for HBCUs.

\subsection{The International Accreditation Council for Business Education (IACBE)}

According to information extracted from its website, the IACBE was founded in 1997 in response to the expressed needs of presidents, chief executive officers, chief academic officers, business deans, chairs, directors, and heads-of-departments who wanted an accreditation process that was not driven by prescriptive standards relating to inputs and resources but was mission-driven and outcomes-based. In January 2011, the IACBE achieved a significant milestone when the Board of Directors of the Council for Higher Education Accreditation (CHEA) granted it recognition. Accrediting business programs that lead to degrees at the associate, bachelor's, master's, and doctoral levels in institutions of higher education, the IACBE has hundreds of member institutions with campuses worldwide and has accredited over 1,300 business and businessrelated programs in the United States, Europe, Asia, the Middle East, Central America and South America. It is the philosophy of the IACBE that academic quality and excellence in business education should be measured in terms of the performance of an academic business unit relative to its mission. Although adequate quantitative and qualitative levels of human, financial, and physical resources are essential contributing factors to academic quality, the focus according to the IACBE should be on the value of those resources in producing measurable results.

The IACBE implements an accreditation process that focuses on the outcomes of the teaching/learning process rather than on prescriptive input standards. In the accreditation process, academic quality is evaluated within the framework of the academic business unit's mission. Stated differently, the IACBE implements a developmental accreditation process based on a quality management systems (QMS) framework that emphasizes efforts to improve the overall effectiveness of the academic business unit. This approach to accreditation is based on the W. Edwards Deming-Michael Porter framework for quality assurance. In the approach, the IACBE focuses on the extent to which an academic business unit achieves its intended student learning and operational outcomes (i.e., on its overall level of performance).

As stated on its website, application fees for candidacy status is $\$ 1,200$, thereafter an application fee for first time accreditation and reaffirmation of accreditation is $\$ 1,700$. Prior to applying for candidacy status, all academic business units that are educational members of the IACBE must have one or more representatives attend a workshop on developing a comprehensive outcomes assessment plan. Developing a comprehensive outcome assessment plan for workshop costs $\$ 500$ and preparing an effective self-study/site visit costs an additional $\$ 500$. Candidacy visit cost for U.S. institutions is $\$ 1,350$. Accreditation site visit cost for U.S. institutions is $\$ 4,200$. Once accreditation has been granted, there is an annual accreditation maintenance fees of $\$ 500$. Extension of candidacy/accreditation status costs $\$ 500$. The application fee for the 
review of new business programs after accreditation has been granted by the Board of Commissioners is $\$ 1,200$ per review. The requirements for accreditation include; to have been granted candidacy status by the IACBE Board of Commissioners and to have at least one set of graduates for which there are outcomes assessment results for each program to be considered for accreditation. Total accreditation cost for institutions in the U.S. is $\$ 5,900$. According to Ashford University Staff (2014), the IACBE has grown into the leading outcomes-based professional accreditation agency for business and management education in colleges and universities, whose primary purpose is excellence in teaching and learning.

\section{DATA AND METHODOLOGY}

Based on information gathered from Hbcu-Colleges.com (2018), a source of facts about HBCU schools in the U.S., including national, regional and state rankings, campus safety ratings and lists of regional competitors, there are eighty-seven HBCU Business Schools within the continental USA plus one in the Virgin Islands. We obtained accreditation data for all the accredited HBCU business schools from the directory listing of members on the websites of the various accrediting agencies. From the data collected, a total of sixty out of eighty-eight HBCU business schools are accredited. Of the sixty accredited HBCU business schools, twenty-three are accredited by the AACSB, thirty-three by the ACBSP and four by the IACBE. We define our sample into two: (1) AACSB accredited and (2) Non-AACSB accredited. AACSB accredited comprises HBCU business schools that are accredited by the AACSB and Non-AACSB accredited comprises those that are accredited by either the ACBSP or the IACBE or both, but not accredited by the AACSB. We set out to compile enrollment data for all the HBCU business schools in both samples from the fact books and enrollment archives from 2009 to 2016 found on the individual school's website. We then narrowed down the test period to 2011 - 2015 because the schools that had enrollment data had complete data for the five-year period. The first sample was originally made up of $23 \mathrm{HBCU}$ business schools while the second was originally made up of thirty-seven HBCU business schools (see Table 2).

From the first sample, we eliminated seven schools that did not have complete enrollment data for our test period. Therefore, the first sample for enrollment analysis comprises sixteen HBCU business schools. From the second sample, we eliminated three community colleges so that every school in the two samples was a four-year degree granting institution and further eliminated twelve schools that did not have enrollment data for the test period. The second sample for enrollment analysis is made up of twenty-two HBCU business schools. Total sample size for the study i.e. AACSB and NonAACSB HBCU Business Schools is 38 (see Tables 3 and 4). After entering the data on an excel spreadsheet, we calculated and determined the enrollment growth rate of the two test samples over the five-year period $2011-2015$. For the enrollment analysis, we performed a T-test, setting alpha $=5 \%$, between the two samples using the rate of change of enrollment over the five-year period.

We defined the hypotheses as below:

Null hypothesis $\left(\mathrm{H}_{0}\right)$ is that there is no difference between the enrollment growth rates of AACSB and Non-AACSB accredited HBCU business schools.

Alternate hypothesis $\left(\mathrm{H}_{1}\right)$ is that there is significant difference between the enrollment growth rates of AACSB and NonAACSB accredited HBCU business schools.

\subsection{TABLES}

The data in Table 1 shows the regional accreditation breakdown of the 102 HBCUs. For example, 78 of the 102 HBCUs are regionally accredited by the Southern Association of Colleges and Schools (SACS). 10 of the 102 HBCUs are regionally accredited by the Middles States Association Commission on Higher Education (MSCHE). 9 of the $102 \mathrm{HBCUs}$ are regionally accredited by the North Central Association of Colleges and Schools (NCA). 2 of the 102 HBCUs are regionally accredited by the Association for Biblical Higher Education, Commission on Association (ABHE). 2 of the $102 \mathrm{HBCUs}$ are regionally accredited by the Transnational Association of Christian Colleges and Schools (TRACS). 1 of the 102 HBCUs are regionally accredited by the Northwest Commission on Colleges and Universities (NWCCU).

In addition, the data in Table 1 shows the main campus geographical location breakdown of the $102 \mathrm{HBCUs}$. The main campuses of 15 out of the $102 \mathrm{HBCUs}$ are in Alabama, a southern border U.S. State. 10 out of the 102 HBCUs main campuses are in North Carolina, a southern border U.S. State. 9 out of the 102 HBCUs main campuses are in Georgia, a southern border U.S. State. 9 out of the 102 HBCUs main campuses are in Texas, a southern border U.S. State. 8 out of the 102 HBCUs main campuses are in South Carolina, a southern border U.S. State. 7 out of the 102 HBCUs main campuses are in Mississippi, a southern border U.S. State. 4 out of the $102 \mathrm{HBCUs}$ main campuses are in Arkansas, a southern border U.S. State. 4 out of the 102 HBCUs main campuses are in Maryland, a northeastern U.S. State. 6 out of the 102 HBCUs main campuses are in Louisiana, a southern border U.S. State. 6 out of the 102 HBCUs main campuses are in Tennessee, a southern border U.S. State. 5 out of the 102 HBCUs main campuses are in Virginia, a southern border U.S. State. 4 out of the 102 HBCUs main campuses are in Florida, a southern border U.S. State. 1 out of the 102 HBCUs main campuses is in Delaware, a northeastern U.S. State. 2 out of the 102 HBCUs main campuses are in Kentucky, a border U.S. State. 2 out of 
the 102 HBCUs main campuses are in Missouri, a border U.S. State. 2 out of the 102 HBCUs main campuses are in Ohio, a midwestern U.S. State. 1 out of the 102 HBCUs main campuses is in Oklahoma, a southwestern U.S. State. 2 out of the 102 HBCUs main campuses are in Pennsylvania, a northeastern U.S. State. 2 out of the $102 \mathrm{HBCUs}$ main campuses are in West Virginia, a southeastern U.S. State. 2 out of the 102 HBCUs main campuses are in the District of Columbia (D.C.), the capital of the United States of America. 1 out of the 102 HBCUs main campuses is in the U.S. Virgin Islands, a territory of the United States.

Table 1: Geographical Location and Regional Accreditation Breakdown of HBCUs

\begin{tabular}{|c|c|c|c|c|c|c|c|}
\hline & SACS & MSCHE & NCA & ABHE & TRACS & NWCCU & TOTAL \\
\hline Alabama & 14 & - & - & 1 & - & - & 15 \\
\hline Arkansas & 1 & - & 3 & - & - & - & 4 \\
\hline Delaware & - & 1 & - & - & - & - & 1 \\
\hline District of Columbia (D.C.) & - & 2 & - & - & - & - & 2 \\
\hline Florida & 4 & - & - & - & - & - & 4 \\
\hline Georgia & 9 & - & - & - & - & - & 9 \\
\hline Kentucky & 2 & - & - & - & - & - & 2 \\
\hline Louisiana & 6 & - & - & - & - & - & 6 \\
\hline Maryland & - & 4 & - & - & - & - & 4 \\
\hline Mississippi & 7 & - & - & - & - & - & 7 \\
\hline Missouri & 1 & - & 1 & - & - & - & 2 \\
\hline North Carolina & 10 & - & - & - & - & - & 10 \\
\hline Ohio & - & - & 2 & - & - & - & 2 \\
\hline Oklahoma & - & - & 1 & - & - & - & 1 \\
\hline Pennsylvania & - & 2 & - & - & - & - & 2 \\
\hline South Carolina & 7 & - & - & - & 1 & - & 8 \\
\hline Tennessee & 4 & - & - & 1 & - & 1 & 6 \\
\hline Texas & 8 & - & 1 & - & - & - & 9 \\
\hline Virginia & 4 & - & - & - & 1 & - & 5 \\
\hline West Virginia & 1 & - & 1 & - & - & - & 2 \\
\hline Virgin Islands & - & 1 & - & - & - & - & 1 \\
\hline TOTAL & 78 & 10 & 9 & $\underline{2}$ & 2 & 1 & 102 \\
\hline Legend & & & & & & & \\
\hline SACS - & \multicolumn{7}{|c|}{ Southern Association of Colleges and Schools } \\
\hline MSCHE - & \multicolumn{7}{|c|}{ Middle States Association Commission on Higher Education } \\
\hline NCA & \multicolumn{7}{|c|}{ North Central Association of Colleges and Schools } \\
\hline ABHE - & \multicolumn{7}{|c|}{ Association for Biblical Higher Education, Commission on Accreditation } \\
\hline TRACS - & \multicolumn{7}{|c|}{ Transnational Association of Christian Colleges and Schools } \\
\hline NWCCU - & \multicolumn{7}{|c|}{ Northwest Commission on Colleges and Universities } \\
\hline
\end{tabular}




\section{Table 2: HBCU - Business School Accreditation Population}

The data in Table 2 identifies how many and which of the $102 \mathrm{HBCUs}$ have secured a business school accreditation. It also identifies which specific business accreditation each HBCU business school has secured. A total of $60 \mathrm{HBCUs}$ business schools are accredited. The business schools of $23 \mathrm{HBCUs}$ are accredited by the Association to Advance Collegiate Schools of Business (AACSB). The business schoos of $33 \mathrm{HBCUs}$ are accredited by the Accreditation Council for Business Schools and Programs (ACBSP). The business schools of $4 \mathrm{HBCUs}$ are accredited by the International Assembly for Collegiate Business Education (IACBE). There are $37 \mathrm{HBCU}$ s business schools that are Non-AACSB accredited.

\begin{tabular}{|c|c|}
\hline AACSB & Non-AACSB (ACBSP or IAFCE or Both) \\
\hline Association to Advance Collegiate Schools of Business (AACSB): & Accreditation Council for Business Schools and Programs (ACBSP): \\
\hline 1 Clark Atlanta University & 1 Alabama State University \\
\hline Delaware State University & Alcorn State University \\
\hline Elizabeth City State University & Benedict College \\
\hline Fayetteville State University & Bethune-Cookman University \\
\hline 5 Grambling State University & Bishop State Community College \\
\hline 6 Howard University & Bluefield State College \\
\hline Jackson State University & Bowie State University \\
\hline Morehouse College & Central State University \\
\hline 9 Morgan State University & Claflin University \\
\hline 10 Norfolk State University & Coppin State University \\
\hline 11 North Carolina A\&T State University & Denmark Technical College \\
\hline 12 North Carolina Central University & Fisk University \\
\hline 13 Prairie View A \& M University & Florida A\& M University \\
\hline 14 Savannah State University & Florida Memorial University \\
\hline 15 South Carolina State University & Harris-Stowe State University \\
\hline 16 Southern University and A\&M College at Baton Rouge & Huston-Tillotson College \\
\hline 17 Southern University at New Orleans & Kentucky State University \\
\hline 18 Tennessee State University & Langston University \\
\hline 19 Texas Southern University & Lawson State Community College \\
\hline 20 Tuskegee University & Miles College \\
\hline 21 University of Maryland, Eastern Shore & Mississippi Valley State University \\
\hline 22 Virginia State University & Morris College \\
\hline \multirow[t]{16}{*}{23 Winston-Salem State University } & Oakwood University \\
\hline & Paine College \\
\hline & Philander Smith College \\
\hline & University of Arkansas at Pine Buff \\
\hline & University of the District of Columbia \\
\hline & University of the Virgin Islands \\
\hline & Virginia Union University \\
\hline & Voorhees College \\
\hline & West Virginia State University \\
\hline & Wiley College \\
\hline & Xavier University of New Orleans \\
\hline & International Assembly for Collegiate Business Education (IACBE): \\
\hline & 1 Edward Waters College \\
\hline & Hampton University \\
\hline & Harris-Stowe State University \\
\hline & Stillman College \\
\hline
\end{tabular}


Table 3: HBCU - Business School Enrollment Data over the Five-Year Period (Fall 2011 - Fall 2015)

Listed below in Table 3 is information pertaining to the accredited HBCU business schools which made up our two samples. Overall, $38 \mathrm{HBCUs}$ business schools were grouped by their form of specialty accreditation. For example, 16 of the $38 \mathrm{HBCU}$ Business schools in our first sample have secured an AACSB Accreditation. 20 of the $38 \mathrm{HBCU}$ Business Schools in our second sample have secured ACBSP Accreditation. 2 of the $38 \mathrm{HBCU}$ Business Schools in our second sample have secured an IACBE Accreditation. As a result, 16 AACSB Accredited and 22 NON-AACSB HBCU business schools made up our two samples, respectively.

In addition to the business school's name and their specialty accreditation grouping, listed in Table 3 is the annual enrollment data of these $38 \mathrm{HBCU}$ Business Schools over the five-year period (Fall 2011 - Fall 2015). Total yearly business school enrollment data comprised of both undergraduate and graduate students.

\begin{tabular}{|c|c|c|c|c|c|c|}
\hline \multicolumn{7}{|c|}{ AACSB } \\
\hline & & \multicolumn{5}{|c|}{ Business School Enrollment } \\
\hline \multicolumn{2}{|c|}{ Association to Advance Collegiate Schools of Business (AACSB): } & Fall 2011 & Fall 2012 & Fall 2013 & Fall 2014 & Fall 2015 \\
\hline 1 & Delaware State University & 777 & 753 & 794 & 862 & 907 \\
\hline 2 & Elizabeth City State University & 433 & 393 & 320 & 258 & 180 \\
\hline 3 & Fayetteville State University & 637 & 639 & 646 & 608 & 715 \\
\hline 4 & Grambling State University & 625 & 633 & 609 & 540 & 529 \\
\hline 5 & Howard University ${ }^{1}$ & 1,160 & 1,100 & 1,133 & 1,129 & 1,100 \\
\hline 6 & Jackson State University & 1,099 & 1,026 & 1,060 & 1,057 & 1,139 \\
\hline 7 & Morehouse College & 633 & 559 & 548 & 518 & 537 \\
\hline 8 & Morgan State University' & 1,352 & 1,345 & 1,247 & 1,304 & 1,292 \\
\hline 9 & Norfolk State University & 872 & 826 & 758 & 751 & 961 \\
\hline 10 & North Carolina A\&T State University ${ }^{1}$ & 1,084 & 1,005 & 1,071 & 1,149 & 1,262 \\
\hline 11 & North Carolina Central University & 1,050 & 1,013 & 923 & 887 & 961 \\
\hline 12 & Savannah State University & 893 & 883 & 899 & 963 & 963 \\
\hline 13 & South Carolina State University & 486 & 420 & 381 & 366 & 336 \\
\hline 14 & Southern University and A\&M College at Baton Rouge & 928 & 846 & 765 & 732 & 769 \\
\hline 15 & Texas Southern University & 1,499 & 1,535 & 1,405 & 1,558 & 1,510 \\
\hline \multicolumn{2}{|r|}{ Virginia State University } & 799 & 784 & 661 & 606 & 559 \\
\hline \multicolumn{7}{|c|}{ Non-AACSB (ACBSP or IAFCE or Both) } \\
\hline & & \multicolumn{5}{|c|}{ Business School Enrollment } \\
\hline \multicolumn{2}{|r|}{ Accreditation Council for Business Schools and Programs (ACBSP): } & Fall 2011 & Fall 2012 & Fall 2013 & Fall 2014 & Fall 2015 \\
\hline 1 & Alabama State University & 657 & 590 & 673 & 552 & 379 \\
\hline 2 & Alcorn State University & 333 & 339 & 308 & 291 & 281 \\
\hline 3 & Bethune-Cookman University & 564 & 587 & 587 & 631 & 427 \\
\hline 4 & Central State University & 533 & 408 & 416 & 383 & 384 \\
\hline 5 & Claflin University & 326 & 312 & 288 & 299 & 308 \\
\hline 6 & Coppin State University & 214 & 271 & 292 & 274 & 290 \\
\hline 7 & Fisk University & 71 & 88 & 84 & 106 & 120 \\
\hline 8 & Florida A\& M University & 1,495 & 1,382 & 1,206 & 1,063 & 965 \\
\hline 9 & Harris-Stowe State University & 588 & 559 & 479 & 458 & 514 \\
\hline 10 & Huston-Tillotson College & 167 & 163 & 203 & 243 & 252 \\
\hline 11 & Kentucky State University & 258 & 232 & 239 & 173 & 143 \\
\hline 12 & Mississippi Valley State University & 306 & 341 & 321 & 372 & 366 \\
\hline 13 & Oakwood University & 295 & 290 & 269 & 263 & 251 \\
\hline 14 & Paine College & 184 & 169 & 185 & 170 & 111 \\
\hline 15 & University of Arkansas at Pine Buff & 415 & 377 & 301 & 331 & 343 \\
\hline 16 & University of the District of Columbia & 525 & 487 & 480 & 487 & 510 \\
\hline 17 & University of the Virgin Islands & 647 & 605 & 589 & 559 & 580 \\
\hline 18 & Voorhees College & 118 & 121 & 60 & 75 & 79 \\
\hline 19 & West Virginia State University & 393 & 359 & 345 & 325 & 412 \\
\hline \multirow[t]{2}{*}{20} & Xavier University of New Orleans & 1,335 & 1,410 & 1,449 & 1,474 & 1,336 \\
\hline & & \multicolumn{5}{|c|}{ Business School Enrollment } \\
\hline \multicolumn{2}{|r|}{ International Assembly for Collegiate Business Education (IACBE): } & Fall 2011 & Fall 2012 & Fall 2013 & Fall 2014 & Fall 2015 \\
\hline 21 & Edward Waters College & 97 & 161 & 138 & 139 & 338 \\
\hline 22 & Hampton University & 664 & 617 & 635 & 596 & 644 \\
\hline
\end{tabular}


Table 4: HBCU - Business School Enrollment Growth Rate over the Five-Year Period (Fall 2011 - Fall 2015)

Listed below in Table 4 is information pertaining to the accredited HBCU business schools which made up our two samples. Overall, $38 \mathrm{HBCUs}$ business schools were grouped by their form of specialty accreditation. For example, 16 of the $38 \mathrm{HBCU}$ Business schools in our first sample have secured an AACSB Accreditation. 20 of the $38 \mathrm{HBCU}$ Business Schools in our second sample have secured ACBSP Accreditation. 2 of the $38 \mathrm{HBCU}$ Business Schools in our second sample have secured an IACBE Accreditation. As a result, 16 AACSB Accredited and 22 NON-AACSB HBCU business schools made up our two samples, respectively.

In addition to the business school's name and their specialty accrediatation grouping, listed in Table 4 is the enrollment growth rate of these $38 \mathrm{HBCU}$ Businss Schools over the five-year period (Fall 2011 - Fall 2015). As evident from Tables 3 and 4, Fall 2011 was the first year enrollment data was collected. With the exception of the Fall 2011 year, the rate of change of enrollment (enrollment growth rate) was cacluated by using the yearly enrollment data reported in Table 3. For example, to calculate the enrollment growth rate for Fall 2012, the actual enrollment data for Fall 2011 was subtracted from the actual enrollment data for Fall 2012, the difference was then divided by the actual enrollment data for Fall 2011 (the previous year). The Average Growth Rate (the final column) reported in Table 4 was calculated by averaging the yearly growth rates over the entire five-year period (Fall 2011 - Fall 2015). We used the average growth rate (the final column reported below) to run our T-Test calculation, please see Table 5 for the T-Test results.

\begin{tabular}{|c|c|c|c|c|c|c|c|}
\hline \multirow{2}{*}{\multicolumn{2}{|c|}{$\frac{\text { AACSB }}{\text { Association to Advance Collegiate Schools of Business (AACSB): }}$}} & \multicolumn{6}{|c|}{ Business School Enrollment Growth Rate Percentage (\%) } \\
\hline & & \multirow{2}{*}{ Fall 2011} & \multirow{2}{*}{$\frac{\text { Fall } 2012}{-3 \%}$} & \multirow{2}{*}{$\frac{\text { Fall } 2013}{5 \%}$} & \multirow{2}{*}{$\frac{\text { Fall } 2014}{9 \%}$} & \multirow{2}{*}{$\frac{\text { Fall } 2015}{5 \%}$} & \multirow{2}{*}{$\frac{\text { Average Growth Rate }}{4 \%}$} \\
\hline 1 & Delaware State University & & & & & & \\
\hline 2 & Elizabeth City State University & - & $-9 \%$ & $-19 \%$ & $-19 \%$ & $-30 \%$ & $-19 \%$ \\
\hline 3 & Fayetteville State University & - & $0 \%$ & $1 \%$ & $-6 \%$ & $18 \%$ & $3 \%$ \\
\hline 4 & Grambling State University & - & $1 \%$ & $-4 \%$ & $-11 \%$ & $-2 \%$ & $-4 \%$ \\
\hline 5 & Howard University & - & $-5 \%$ & $3 \%$ & $0 \%$ & $-3 \%$ & $-1 \%$ \\
\hline 6 & Jackson State University & - & $-7 \%$ & $3 \%$ & $0 \%$ & $8 \%$ & $1 \%$ \\
\hline 7 & Morehouse College & - & $-12 \%$ & $-2 \%$ & $-5 \%$ & $4 \%$ & $-4 \%$ \\
\hline 8 & Morgan State University & - & $-1 \%$ & $-7 \%$ & $5 \%$ & $-1 \%$ & $-1 \%$ \\
\hline 9 & Norfolk State University & - & $-5 \%$ & $-8 \%$ & $-1 \%$ & $28 \%$ & $3 \%$ \\
\hline 10 & North Carolina A\&T State University & - & $-7 \%$ & $7 \%$ & $7 \%$ & $10 \%$ & $4 \%$ \\
\hline 11 & North Carolina Central University & - & $-4 \%$ & $-9 \%$ & $-4 \%$ & $8 \%$ & $-2 \%$ \\
\hline 12 & Savannah State University & - & $-1 \%$ & $2 \%$ & $7 \%$ & $0 \%$ & $2 \%$ \\
\hline 13 & South Carolina State University & - & $-14 \%$ & $-9 \%$ & $-4 \%$ & $-8 \%$ & $-9 \%$ \\
\hline 14 & Southern University and A\&M College at Baton Rouge & - & $-9 \%$ & $-10 \%$ & $-4 \%$ & $5 \%$ & $-4 \%$ \\
\hline 15 & Texas Southern University & - & $2 \%$ & $-8 \%$ & $11 \%$ & $-3 \%$ & $0 \%$ \\
\hline \multirow[t]{2}{*}{16} & Virginia State University & - & $-2 \%$ & $-16 \%$ & $-8 \%$ & $-8 \%$ & $-8 \%$ \\
\hline & Non-AACSB (ACBSP or IAFCE or Both) & \multicolumn{6}{|c|}{ Business School Enrollment Growth Rate Percentage (\%) } \\
\hline \multicolumn{2}{|r|}{ Accreditation Council for Business Schools and Programs (ACBSP): } & Fall 2011 & Fall 2012 & Fall 2013 & Fall 2014 & Fall 2015 & Average Growth Rate \\
\hline 1 & Alabama State University & - & $-10 \%$ & $14 \%$ & $-18 \%$ & $-31 \%$ & $-11 \%$ \\
\hline 2 & Alcorn State University & - & $2 \%$ & $-9 \%$ & $-6 \%$ & $-3 \%$ & $-4 \%$ \\
\hline 3 & Bethune-Cookman University & - & $4 \%$ & $0 \%$ & $7 \%$ & $-32 \%$ & $-5 \%$ \\
\hline 4 & Central State University & - & $-23 \%$ & $2 \%$ & $-8 \%$ & $0 \%$ & $-7 \%$ \\
\hline 5 & Claflin University & - & $-4 \%$ & $-8 \%$ & $4 \%$ & $3 \%$ & $-1 \%$ \\
\hline 6 & Coppin State University & - & $27 \%$ & $8 \%$ & $-6 \%$ & $6 \%$ & $9 \%$ \\
\hline 7 & Fisk University & - & $24 \%$ & $-5 \%$ & $26 \%$ & $13 \%$ & $15 \%$ \\
\hline 8 & Florida A\& M University & - & $-8 \%$ & $-13 \%$ & $-12 \%$ & $-9 \%$ & $-10 \%$ \\
\hline 9 & Harris-Stowe State University & - & $-5 \%$ & $-14 \%$ & $-4 \%$ & $12 \%$ & $-3 \%$ \\
\hline 10 & Huston-Tillotson College & - & $-2 \%$ & $25 \%$ & $20 \%$ & $4 \%$ & $11 \%$ \\
\hline 11 & Kentucky State University & - & $-10 \%$ & $3 \%$ & $-28 \%$ & $-17 \%$ & $-13 \%$ \\
\hline 12 & Mississippi Valley State University & - & $11 \%$ & $-6 \%$ & $16 \%$ & $-2 \%$ & $5 \%$ \\
\hline 13 & Oakwood University & - & $-2 \%$ & $-7 \%$ & $-2 \%$ & $-5 \%$ & $-4 \%$ \\
\hline 14 & Paine College & - & $-8 \%$ & $9 \%$ & $-8 \%$ & $-35 \%$ & $-10 \%$ \\
\hline 15 & University of Arkansas at Pine Buff & - & $-9 \%$ & $-20 \%$ & $10 \%$ & $4 \%$ & $-4 \%$ \\
\hline 16 & University of the District of Columbia & - & $-7 \%$ & $-1 \%$ & $1 \%$ & $5 \%$ & $-1 \%$ \\
\hline 17 & University of the Virgin Islands & - & $-6 \%$ & $-3 \%$ & $-5 \%$ & $4 \%$ & $-3 \%$ \\
\hline 18 & Voorhees College & - & $3 \%$ & $-50 \%$ & $25 \%$ & $5 \%$ & $-4 \%$ \\
\hline 19 & West Virginia State University & - & $-9 \%$ & $-4 \%$ & $-6 \%$ & $27 \%$ & $2 \%$ \\
\hline 20 & Xavier University of New Orleans & - & $6 \%$ & $3 \%$ & $2 \%$ & $-9 \%$ & $0 \%$ \\
\hline \multicolumn{2}{|c|}{ International Assembly for Collegiate Business Education (IACBE): } & Fall 2011 & Fall 2012 & Fall 2013 & Fall 2014 & Fall 2015 & Average Growth Rate \\
\hline 21 & Edward Waters College & - & $66 \%$ & $-14 \%$ & $1 \%$ & $143 \%$ & $49 \%$ \\
\hline 22 & Hampton University & - & $-7 \%$ & $3 \%$ & $-6 \%$ & $8 \%$ & $-1 \%$ \\
\hline
\end{tabular}




\section{RESULTS}

If $\mathrm{t}$ Stat $<-\mathrm{t}$ Critical two-tail or $\mathrm{t}$ Stat $>\mathrm{t}$ Critical two-tail, we reject the null hypothesis. From Table 5 below, $\mathrm{t}$ Stat $=0.819$ and $t$ Critical two tail $=2.037$ which implies $t$ Stat is not less than $-t$ Critical two-tail and is not greater than $t$ Critical two-tail. We therefore fail to reject the null hypothesis. The observed difference between the sample means is not statistically significant to justify the conclusion that, the enrollment growth rate at AACSB and Non-AACSB accredited HBCU Business Schools are different.

Table 5: T-Test: Two Sample Unequal Variances (Using the 5-year Average Growth Rate reported in Table 4)

\begin{tabular}{lrr}
\hline & NON-AACSB & \multicolumn{1}{c}{ AACSB } \\
\hline Mean & 0.004055802 & -0.021780521 \\
Variance & 0.016721527 & 0.003755194 \\
Observations & 22 & 16 \\
Hypothesized Mean Difference & 0 & \\
df & 32 & \\
t Stat & 0.819161597 & \\
P(T<=t) one-tail & 0.209376738 & \\
t Critical one-tail & 1.693888748 & \\
P(T<=t) two-tail & 0.418753476 & \\
t Critical two-tail & 2.036933343 & \\
\hline
\end{tabular}

\section{CONCLUSION}

All the three-business school accrediting agencies in this study are nonprofit organizations and international in scope. Each one evaluates programs at the bachelors, master's and doctoral levels and as of 2011, they are all officially recognized by the Council for Higher Education Accreditation (CHEA). It is important to note that most businesses and universities reviewing transcripts and accepting degrees base their decisions on institutional accreditation and not on specialty accreditation (ACBSP Accreditation, 2018). Whether approved by the AACSB, the IACBE, or the ACBSP, students can be sure that their business programs have legitimate accreditations endorsed by the CHEA. Each of the three is a mark of distinction for academic business schools and programs. Where the AACSB is prescriptive and research-oriented, guiding schools in their structure and curriculum, the IACBE and the ACBSP follow a more results-based approach to ensure student success (Ashford University Staff, 2014). Despite its reputation and cost, we did not find in this study, that the AACSB accreditation leads to greater gains in enrollment growth at HBCU Business Schools over time.

Given the precarious financial circumstances of HBCUs, preference for the AACSB should therefore be leveraged on other factors and not on the expectation of gains in enrollment. With or without the AACSB accreditation, HBCUs should tell their contemporary story; the history and legacy are formidable and essential, but the real story is what HBCUs are doing today and what they have the potential to contribute in the future (Gasman, 2009). HBCUs offer all students, regardless of race, an opportunity to develop their skills and talents. These institutions train young people, who go on to serve domestically and internationally in various professions as entrepreneurs and in the public and the private sectors. They are a source of accomplishment and great pride for the African-American community, as well as the entire nation (White House Initiative on Historically Black Colleges and Universities, 2018). This study is limited to HBCUs and focuses on just one of the key operational performance indicators (enrollment). We recommend for future studies, an investigation of the impact of the AACSB accreditation on other key operational performance indicators for example graduation rate, retention rate, and on the ranking of HBCU Business Schools. 


\section{REFERENCES}

AACSB Accreditation Standards. (2018). AACSB.edu. Retrieved on March 7, 2018, from https://www.aacsb.edu/accreditation/standards/

ACBSP Accreditation. (2018). ACBSP.org. Retrieved on March 5, 2018, from https://www.acbsp.org/page/accreditation?

About the IACBE (2018). The International Accreditation Council for Business Education (IACBE) website. Retrieved on March 21, 2018, from

http://iacbe.org/about-page/

Ashford University Staff (2014). Business School Accreditation-What's the Difference? Retreived on March 4, 2018, from https://www.ashford.edu/blog/online-learning/business-school-accreditation-whats-the-difference

Business School (2018). BusinessDictionary.com. Retreived on March 2, 2018, from http://www.businessdictionary.com/definition/business-school.html

CHEA and USDE-Recognized Accrediting Organizations (2018, April). Council for Higher Education Accreditation. Retreived on March 14, 2018, from https://www.chea.org/userfiles/Recognition/CHEA_USDE_AllAccred.pdf

Credle, S.H., Maheshwari, S., \& Pridgen, J. (2010, Spring/ Summer). An Alternative Ranking Methodogology of the Best Colleges and Universities for Africian-Americans. The Journal of Business and Finance Research. Vol. 2, Issue 1, p. 51-69.

Fast Facts - Historically Black Colleges and Universities (2018). National Center for Education Statistics.

Retreived on March 8, 2018, from https://nces.ed.gov/fastfacts/display.asp?id=667

From MBA to CEO, where do chief executives of companies in the FT 500 go to business schools? (2018) Financial Times Online Retreived on March 7, 2018, from https://ig.ft.com/sites/mba-to-ceo/

Gasman, M. (2009). Historically Black Colleges and Universities in a Time of Economic Crisis.Academe, Retrieved from http://repository.upenn.edu/gse_pubs/349

Gee, K (2017, September 17). MBA Applications Decline for Third Year in a Row. The Wall Street Journal Online.

Guttenplan, D. D., (2011). Accrediting Business Schools - by Whose Rules. New York Times Online, Retrieved on March 7, 2018, from http://www.nytimes.com/2011/06/27/world/europe/27iht-educLede27.html

HBCU Schools Offering Business Program - Top 50 (2017). HBCU Colleges.com. Retrieved on March 8, 2018, from http://hbcucolleges.com/business

Hedrick, D. W., Henson, S. E., Krieg, \& J. M. (2010).The Effects of AACSB Accreditation on Faculty Salaries and Productivity. Journal of Education for Business, 85: 284-291.

Henninger, E. (2000). Expanding American Collegiate Business School and Program Accreditation: Adding Value or Confusion. Academy of Educational Leadership Journal, Vol. 4, Number 2.

Historically Black Colleges and Universities: Recent Trends. (2006, November). American Association of University Professors.org. Retrieved on February 22, 2018, from https://www.aaup.org/report/historically-black-colleges-and-universities-recent-trends

IACBE: http://iacbe.org/accreditation.asp, Retrieved on March 7, 2018, from http://iacbe.org/accreditation-requirements-foraccreditation.asp

Importance of Accreditation (2018). Accrediting Council for Independent Colleges and Schools. Retrieved on March 8, 2018, from http://www.acics.org/students/content.aspx?id=4320

Johnson, M., Bruch, J., \& Gill, B. (2015). Changes in Financial Aid and Student Enrollment at Historically Black Colleges and Universities after Tightening of the PLUS Credit Standards (REL 2015-082). Washington, DC: U.S. Department of Education, Institute of Education Sciences, National Center for Education Evaluation and Regional Assistance, Regional Educational Laboratory Mid-Atlantic. Retrieved on March 7, 2018, from https://files.eric.ed.gov/fulltext/ED555652.pdf

Kelsey, G. (2017, September 18). M.B.A. Applications Decline for Third Year in a Row. Wall Street Journal.

Retrieved on March 7, 2018, from https://www.wsj.com/articles/m-b-a-applications-decline-for-third-year-in-a-row-1505727000

Kemelgor, B. H., Johnson, S.D. \& Srinivasan, S. (2000). Forces Driving Organizational Change: A Business School Perspective, Journal of Education for Business 75 (3): 133-137.

Rafol, G. (2017, May 2). ACBSP Dues Increasing for the 2017-18 Membership Year [website post]. Retrieved on March 7, 2018, from https://www.acbsp.org/news/news.asp?id=343386\&hhSearchTerms=\%22dues\%22

Roller, R.H., Andrews, B.K., \& Bovee, S.L (2003). Specialized Accreditation of Business Schools: A Comparison of Alternative Costs, Benefits, and Motivations. Journal of Education for Business, Vol. 78 (4), p. 197-204.

Sciglimpaglia D., Medlin C., Toole H., \& Whittenberg G., E. (2006). Business School Accreditation: A Survey of Australian Academics.

Conference Presentation. Retrieved on March 8, 2018, from

http://www.academia.edu/7660364/BUSINESS_SCHOOLS_ACCREDITATION_A_SURVEY_OF_AUSTRALIAN_ACADEMICS 
Terhune, C. (2011). The Problems Some Business Schools Hide from Students. The Fiscal Times Online, Nov. 2, 2011, p. 1-2.

Understanding Accreditation (2018), College and Degrees.com. Retreived on March 11, from http://www.collegesanddegrees.com/accreditation

White House Initiative on Historically Black Colleges and Universities (2018). U.S. Department of Education website. Retrieved on March 8 , 2018, from https://sites.ed.gov/whhbcu/one-hundred-and-five-historically-black-colleges-and-universities/

Whittenberg, G. E., Toole H., Sciglimpaglia D., \& Medlin C. (2004). AACSB International Accreditation, An Australian Perspective. The Journal of Academic Higher Education, Spring-Fall 2006, p. 9-14. 